\title{
Carbon Emission Disclosure and Profitability - Evidence from Manufacture Companies in Indonesia
}

\section{Salbiah and Hasan Mukhibad}

Accounting Department, Economics Faculty, Universitas Negeri Semarang, Universitas Negeri Semarang Gedung L2, Kampus Sekaran Gunungpati, Semarang Jawa Tengah 50229, Indonesia

\section{Abstract}

This research aims to prove empirically the effect of size, leverage, and composition of the board of commissioners to carbon emission disclosure (CED) and the effect of CED on future profitability. The population of this study are a manufacturing companies listed on the Indonesia Stock Exchange (BEI). Samples were determined by purposive sampling and 107 units of analysis were obtained. Data analysis using path analysis

Corresponding Author: Hasan Mukhibad hasanmukhibad@mail unnes.ac.id

Received: 7 August 2018 Accepted: 15 September 2018 Published: 22 October 2018

Publishing services provided by Knowledge E

(c) Salbiah and Hasan Mukhibad. This article is distributed under the terms of the Creative Commons

Attribution License, which permits unrestricted use and redistribution provided that the original author and source are credited.

Selection and Peer-review under the responsibility of the ICE-BEES 2018 Conference Committee.

\section{G OPEN ACCESS} method. The results shows that size has a positive effect on CED. Leverage and ratio of independent board commissioners have no impact on CED. Leverage has a negative effect on profitability. Size and ratio of independent commissioners have no effect on profitability. Companies that has high CED have not affect to future profitability. Furthermore, CED variables is not as mediate variable between size, leverage, independent board ratio on profitability. The implications of the result study are that CEDs that are still voluntary have not had a beneficial impact on the company. Suggestions for regulators to increase awareness of corporate, and community to use CED indicators as main indicator in deciding investment and other business policies.

Keywords: Carbon Emission Disclosure (CED), Profitability, Size, Leverage, and Board Independent.

\section{Introduction}

Data was listed in Word Resources Institute (WRI) in 2001-2013 shows that Indonesia has contribute carbon emissions the second largest after Brazil from 22 tropical countries [35]. Industrial companies are the main targets for reducing carbon dioxide by 10.8 million tons and subsequent transportation companies by 9.8 million tons [45]. The high carbon emissions in Indonesia are not comparable with the disclosure of the environment in companies in Indonesia. Because, Indonesia companies have low environment disclosure. Indonesian companies has carbon emissions disclosure 
average 34,39\% [5]. Moreover, corporate disclosure in Indonesian companies is lower than India, Malaysia, Philippines, Singapore, South Korea, and Thailand companies [17].

This phenomenon is caused the awareness of business actors towards environmental still low. The environmental impacts of the company's activities have been regulated by the Financial Accounting Standards. In Indonesia, Financial Accounting Standards setter (Ikatan Akuntan Indonesia - IAI) who was establish SFAS No. 1 (revised 2016) paragraph fourteen. Developed countries have been paying attention to environmental issues. Consequently, many companies disclose their environmental information in annual reports [23].

Many researchers show that there are several factors for companies to report carbon emissions activities on the annual report. Liao, Luo, \& Tang (2014) states that board of commissioners has influence on environmental reporting. Krishnamurti \& Velayutham (2017) shows that standalone risk management committee has no effect on carbon emissions disclosure. In other hand, Rahman, Rasid, \& Basiruddin (2017) shows there a significantly positive association between the number of directors serving on the board and the quality of voluntary carbon reporting and board independence and CEO duality did not exhibit any significant role in influencing companies to provide highquality information.

Meanwhile, some researchers have proved empirically that there are a significant relationship between leverage, and size of carbon emissions disclosure. Luo \& Tang (2014) states that creditors will request carbon information to evaluate the company risks and related with their debt contracts. Pratiwi (2017) stated that size and leverage have no effect on carbon emission disclosure. In contrast, Ufere, Buang \& Uche (2016) state that the company will consider the size of the company on the impact of the environmental impact. Yuliana (2008) and Anggraeni (2015) indicate that profitability as a trigger for companies to expand their financial statement information. The novelty in this research is use future profitability variable as predictor variable which has effect to carbon emission disclosure including the size, leverage, and independent commissioner ratio as variables that have effect to carbon emissions disclosure.

\subsection{Signaling theory, legitimacy, and stakeholders theory}

Signaling theory is used to describe the behavior of two parties (individuals or organizations) in receiving information derived from the financial statements. The information provider must choose how to communicate the information. On the other hand, the recipient of information (stakeholders) should choose, describe, and interpret the 
information derived from financial statements, annual report and others information (in the form of signals) [13]. Signaling theory is also used to describe the processes used by user in information gap situations [9]. The company will signal to the public the seriousness of the company's commitment to improve environmental sustainability by presenting its carbon footprint [26, 29].

Organizational legitimacy can be measured through the company's ability to fulfill people's wishes [19]. Lanis \& Richardson (2012) argues that the legitimacy of the theory provides an explanation as to why companies disclose more CSR information than other information, extensively used to explain explains the motivation of the organization to voluntarily disclose the environment [31].

Stakeholder Theory showed that a company is not an entity that only operates for its own benefit but the company must provide benefits to stakeholders (shareholders, creditors, consumers, suppliers, governments, communities, analysts and others) [10, 19]. One of the communities interest to the company is the company's concern for the environment. The corporation will communicates the information through a tool in order to gain legitimacy and to maintain its legitimacy according to stakeholder needs [30]. The strengths of stakeholders will improve environmental reporting [58]. Thus, it can be concluded that based on stakeholders theory, emphasizes the company to have responsibility to the environment.

\subsection{Hypotheses development}

Company size is a variable that is often used to describe Corporate Social Responsibility (CSR) disclosures [25]. Companies tend to use environment-based performance to justify or legitimize company activity [19]. Yanto \& Muzzammil (2016) show that size has a significant effect on environmental reporting. If firm want growth from small to large companies, they should be aware of what changes are their obligations [28]. High performance companies will be comparable to the high pollution industry [44]. Thus the hypothesis can be constructed as follows:

H1: Firm size has significant positive effect on carbon emission disclosure level (CED).

Companies that have large debts indicate the company has a great risk too [3]. Creditor will press companies to disclose environmental issues in annual report for assessment of future debt [12]. Companies that have high leverage tend more obligation to meet creditor information needs [37]. Villiers, Naiker, \& Staden (2011) suggested that there is a positive relationship between the debt on disclosure of the environment. 
Firms which has high leverage tend to be more diligent in reporting their environmental activities [58]. Based on the theory and some of the above research can be formulated hypothesis as follows:

H2: Leverage has significant positive effect on carbon emission disclosure (CED)

Good corporate governance mechanism is a key to increase corporate performance. A kind of corporate governance mechanism is the board of commissioners [2]. Stakeholder theories state that to explain how companies monitor toward the relationships among stakeholders with the information company [19]. In the ethics, stakeholders support the company's concern for the social and the environment [51]. Boards with greater independence or neighborhood committees exhibit a greater tendency toward ecological transparency [29]. The level of independence of the board of commissioners is positively related to the level of voluntary disclosure, this is due to the role of the board of commissioners to monitor and control strategic decisions in a company [52]. Based on the reason, can develop hypothesis as below:

$\mathrm{H}_{3}$ : The composition of board of commissioner has a spositive effect on carbon emission disclosure (CED)

The theory of legitimacy focuses on corporate interaction with society [6]. Babalola (2013) states that company size plays an important role in determining the type of relationships a company enjoys within and outside its operating environment. Company size can be defined as the number of variations in production capacity, production capability and the number of services provided to its customers. Firm size is often used as a determinant factor of profitability on a traditional scale [38]. Doğan (2013) said that big companies have greater competitiveness than small companies. Large companies have a larger market share than small companies, so big companies have big opportunity to earn increase profits. Moreover, large companies tend to be stable and had good business prospects and have larger economies of scale [58]. Based on the study studies above it can be formulated hypothesis as follows:

H4: Company size has a positive impact on profitability

The Company may use its debt or capital to finance its business activities. This is because the debt as a trigger the company's growth compared to when using its own capital [58]. Leverage is the highest factor among other factors that can affect the profitability of the company. In good economic periods, high levels of debt can benefit firms. On the bad economic condition, leverage could be reduce company's profitability 
[1]. The high leverage will increase the chances of bankruptcy whose impact will shake investor confidence [40]. The Company will still consider the composition of the capital structure with its debt in running the company. Thus the hypothesis can be constructed as follows:

H5: Leverage has a negative effect on company profitability

Several researchers show the characteristics of the board is able to increase the value of the company Hidayat \& Utama (2003). Independent commissioners can control managers not to do any harm to the company [56]. The company will benefit stakeholders, with an indication of better profitability. The existence of an independent board of commissioner can provide management control in the company's operations [39]. The effectiveness of the board of commissioners on management monitoring and subsequently impacts the company's performance [8]. Thus independent commissioners can affect profitability.

H6: Independent Board of Commissioners has positive effect on profitability

The company is seen as an organization that must conform with the rules of society to ensure the legitimacy of society and can continue to exist [53]. The basis for legitimacy disclosure becomes an additional challenge in the future [36]. The carbon footprint is used to demonstrate the leverage response so the company can signal that they have implemented their social contract [21]. CSR activities impact on future earnings and cash flow, investors will find out when disclosure of information for investment decisions [34]. In fact social disclosure is often linked to allocations to lucrative activities [14]. Thus it can be concluded that disclosure of carbon emissions affects profitability in the coming period.

H7: Disclosure of carbon emissions has a significant positive effect on profitability in the coming year

Firm size is the dominant factor for the disclosure of greenhouse gas emissions, large companies in the future should disclose mandatory GHG emission reports on the basis of liability rather than policy [18]. Leverage is a specific corporate character associated with voluntary disclosure [18]. Companies that increase disclosures equivalent to an increase in debt will allow investors or creditors to assess overall financial risk and long-term debt [24]. The higher proportion of independent board of commissioners will increasingly influence top management decisions as they have higher levels of 
monitoring [29]. The proportion of independent board of commissioners influences the level of voluntary disclosure [16].

Carbon emissions have a significant influence on business activity and behavior, some studies have analyzed the carbon emission link with firm value [50], CSR disclosure has a significant positive effect on financial performance [53]. The impact desired by investors is to get social value and profit related to its investment [34]. The study was used to construct the following indirect effect hypothesis:

H8: Size has positive effect on profitability through CED

H9: Leverage has positive effect on profitability through CED

H10: Independent Board has positive effect on profitability through CED.

\section{Research methods}

The population in this study is manufacturing industry companies listed on the Stock Exchange with observation period 2014-2016 and result 149 entities. Sample used purposive sampling methods and result 107 entities as research sample.

The operational definitions of the independent and the dependent variables are:

TABLE 1: The operational definitions Variables.

\begin{tabular}{|c|c|c|c|c|}
\hline No & Variable & Definition & Measurement & Peneliti \\
\hline 1. & $\begin{array}{l}\text { Carbon } \\
\text { Emmission } \\
\text { Disclosure } \\
\text { (CED) }\end{array}$ & $\begin{array}{l}\text { Disclosure of } \\
\text { carbon emissions } \\
\text { as specified in the } \\
\text { annual report. }\end{array}$ & $\begin{array}{l}\text { Scores on each disclosure item } \\
\text { (Carbon Emissin Disclosure } \\
\text { Checklist) with a dichotomy scale. } \\
\text { The maximum score of } 18 \text {, while the } \\
\text { minimum score is } 0 \text {. Each item is } \\
\text { worth } 1 .\end{array}$ & $\begin{array}{l}\text { Irwhantoko \& } \\
\text { Basuki (2016), } \\
\text { Choi et al., (2013) }\end{array}$ \\
\hline 2. & $\begin{array}{l}\text { Profitability } \\
(\text { ROA) } t+1\end{array}$ & $\begin{array}{l}\text { The company's } \\
\text { ability to make a } \\
\text { profit. }\end{array}$ & $=\frac{\text { Profit After Tax }}{\text { Total Assets }}$ & $\begin{array}{l}\text { Winarsih \& } \\
\text { Solikhah (2015) }\end{array}$ \\
\hline 3. & $\begin{array}{l}\text { Commissioner } \\
\text { Independent } \\
\text { board }\end{array}$ & $\begin{array}{l}\text { Commissioners } \\
\text { from outside the } \\
\text { company. }\end{array}$ & $=\frac{\text { Independent Commissioner }}{\text { Commissioner }}$ & Widyati (2013) \\
\hline 4. & Assets (size) & $\begin{array}{l}\text { The size of a } \\
\text { company indicated } \\
\text { by total assets }\end{array}$ & Ln Total Assets & $\begin{array}{l}\text { Andriyani \& } \\
\text { Khafid, (2014), } \\
\text { Luo \& Tang, } \\
\text { (2014) }\end{array}$ \\
\hline 5. & Leverage & $\begin{array}{l}\text { It is the company's } \\
\text { ability to meet } \\
\text { long-term } \\
\text { obligations. }\end{array}$ & $=\frac{\text { Total Hutang }}{\text { Total Aset }}$ & $\begin{array}{l}\text { Mujiyono \& Nany } \\
\text { (2010), Luo \& } \\
\text { Tang, (2014). }\end{array}$ \\
\hline
\end{tabular}


Hypothesis testing using path analysis significance level $\alpha=0,05$. The path analysis used was multiple regression with SPSS 20 using two regression equations.

TABLE 2: The result of The First Regression.

\begin{tabular}{l|c|c|c|c|c|}
\hline \multicolumn{7}{|c|}{ Coefficients $^{a}$} \\
\hline Model & Unstandardized Coefficients & $\begin{array}{c}\text { Standardized } \\
\text { Coefficients }\end{array}$ & T & Sig. \\
\hline $1 \quad$ B & Std. Error & Beta & \\
\hline Siz &,- 541 &, 352 & & $-1,536$ &, 128 \\
\hline Lev &, 038 &, 012 &, 294 & 3,169 &, 002 \\
\hline Boardind &,- 103 &, 087 &,- 111 & $-1,192$ &, 236 \\
\hline
\end{tabular}

Hypothesis testing the effect of size on CED showed a significant positive effect. In line with Ghomi \& Leung (2013) stating that company size is the dominant factor in the disclosure of greenhouse gas emissions. The statement was supported by Qian, Hörisch, \& Schaltegger (2017) who found that company size has a significant contribution to carbon management.

Leverage to CED is not significant. In line with the results of research Mujiyono \& Nany (2010) which shows that leverage has a negative but not significant effect on the area of voluntary disclosure. Other findings suggest leverage has a negative impact on the disclosure of environmental impacts [14]. Firms with high levels of leverage may be reluctant to publish their carbon emissions reports and are likely to inform a bit of carbon pollution information [41].

The composition of the independent board of commissioners is stated not to have a significant effect on the area of carbon emissions disclosure. In line with Winarsih \& Solikhah, (2015) that independent commissioners have no effect on environmental disclosure quality. The role of the board of commissioners as referred to by Villiers, Naiker, \& Staden (2011) that the board of commissioners provides an overview of the potential potential environmental opportunities. The more independent the board of commissioners will lead to disclosure of information to reduce the risk of information asymmetry in the future [18]. The results of this study are not in line with Nurkhin (2010) which states that the board of independent commissioners has a significant effect on the area of environmental disclosure. 
TABLE 3: The result of The Second Regression.

\begin{tabular}{|l|c|c|c|c|c|}
\hline \multicolumn{7}{|c|}{ Coefficients $^{a}$} \\
\hline Model & Unstandardized Coefficients & $\begin{array}{c}\text { Standardized } \\
\text { Coefficients }\end{array}$ & T & Sig. \\
\hline 1 & B & Std. Error & Beta & \\
\hline (Constant) &, 029 &, 097 & &, 296 &, 768 \\
\hline Siz &, 000 &, 003 &, 004 &, 044 &, 965 \\
\hline Lev &,- 084 &, 024 &,- 326 & $-3,555$ &, 001 \\
\hline Boardind &, 097 &, 056 &, 158 & 1,717 &, 089 \\
\hline CED &, 047 &, 027 &, 168 & 1,747 &, 084 \\
\hline
\end{tabular}

The results of statistical tests showed no significant relationship between firm size and profitability. This research is in line with the research of Yanto \& Muzzammil (2016) which states the size has no significant effect on profitability. Niresh \& Velnampy (2014) explains that firm size has a weak influence on corporate profitability because of shifting management focus from profit maximization to maximizing benefits. This indicates that the size of the company can not explain and predict increase in profitability [55].

Leverage with profitability shows a significant negative relationship. The greater the proportion of debt used for a firm's capital structure, the less likely it is to gain [49]. The presence of these significant and negative effects indicates that the greater the leverage signifies the size of the debt ratio with assets affecting the decrease in profitability [55]. Unlike said by Pratama \& Wiksuana (2016) argues that leverage has a positive and significant effect on Profitability. Ahmad et al., (2015) confirm that the relationship between profitability and leverage is very significant and significant where it indicates that high-profit firms are more interested in using internal funding for their operations.

The composition of the independent commissioner of the company's ability to generate profits shows insignificant results. This result is allegedly because the board of commissioners is not maximizing its role. This research is not in line with Widyati (2013) who said that supervision conducted by independent commissioner can influence manager behavior in an effort to improve company performance. The size of the board has no effect on the value of the company, the company should be able to maximize board size according to firm size [40]. The role of independent board of 
commissioners is seen in their role mechanism in helping to improve profitability not only for shareholders but for stakeholders [8].

Testing the CED hypothesis on profitability showed no significant effect. Increased disclosure of GHG emissions indicates a management perception of the legitimacy and usefulness of disclosure of GHG emissions to increase community confidence [30]. Primc \& Čater (2015) explains that environmental activity is not always associated with an increase in company performance. However, business organizations are required to calculate their social and environmental impacts [33], companies must respond to climate change caused by GHG emissions by industry mechanisms and policies with regard to carbon emissions [48].

TABLE 4: Sobel Test Calculation.

\begin{tabular}{l|c|c|c|c|c|c|c|}
\hline Variabel & $a$ & $b$ & Sa & Sb & Sab & axb & $T$ \\
\hline Size & 0,038 & 0,047 & 0,012 & 0,027 & 0,0019 & 0,0018 & 0,9396 \\
\hline leverage & $-0,103$ & 0,047 & 0,087 & 0,027 & 0,0068 & $-0,0048$ & $-0,7163$ \\
\hline board ind & $-0,29$ & 0,047 & 0,205 & 0,027 & 0,0176 & $-0,0136$ & $-0,7751$ \\
\hline
\end{tabular}

Source: data processed in 2018

The Sobel test is used to test the hypothesis of the mediation variable against variable $\mathrm{Y}$. The test of sobel is calculated to humiliate the following formula:

$$
\begin{gathered}
S a b=\sqrt{b^{2} S a^{2}+a^{2} S b^{2}+S a^{2} S b^{2}} \\
t=\frac{a b}{S a b}
\end{gathered}
$$

$T$ Value on the next test results compared with t table that is worth 1.9813. if $t$ arithmetic $>t$ table then have a significant effect.

The indirect effect of the three variables shows that CEDs are not able to mediate against profitability. Reaffirmed that disclosure of carbon emissions is not necessarily linked to earnings, information disclosure may develop industry targets and disclosure practices that are more specific to the interests of stakeholders [11]. Environmental decisions affect organizational activities including production, marketing and distribution, and human resources to integrate that need special strategies to increase company value [44].

\section{Conclusion}

This research was evidence that size has a significant positive effect on carbon emission disclosure. Leverage and independent board of commissioner have no effect to 
CED and leverage has a significant negative effect on profitability. While size independent board of commissioner have no effect on the profitability. The CED variable is not able to mediate variable among size, leverage and independent board of commissioners towards profitability.

Further research may use other variables that may be directly related to disclosure of carbon emissions such as environmental performance, risk appraisers and age. The use of checklist indicators on carbon emissions reports can also be expanded with indicators released by Global Reporting Initiavie (GRI). Regulators to increase awareness of corporate, and community to use CED indicators as main indicator in deciding investment and other business policies.

\section{References}

[1] Ahmad, N., Salman, A., \& Shamsi, A. F. (2015). Impact of Financial Leverage on Firms 'Profitability: An Investigation from Cement Sector of Pakistan. Research Journal of Finance And Accounting, 6(7), 75-81.

[2] Akhiroh, T., \& Kiswanto. (2016). The Determinant Of Carbon Emission Disclosures. Accounting Analysis Journal, 5(4), 326-336.

[3] Andriyani, R., \& Khafid, M. (2014). Analisis Pengaruh Leverage, Ukuran Perusahaan dan Voluntary Disclosure Terhadap Manipulasi Aktivitas Riil. Accounting Analysis Journal, 3(3), 273-281.

[4] Anggraeni, D. Y. (2015a). Pengungkapan Emisi Gas Rumah Kaca, Kinerja Lingkungan, dan Nilai Perusahaan. Jurnal Akuntansi Dan Keuangan, 12(2), 188-209.

[5] Anggraeni, D. Y. (2015b). Pengungkapan Emisi Gas Rumah Kaca, Kinerja Lingkungan, Dan Nilai Perusahaan - (Greenhouse Gas Emission Disclosure, Environmental Performance, and Firm Value). Jurnal Akuntansi Dan Keuangan Indonesia, 12(2), 188209.

[6] Aulia, F. Z., \& Agustina, L. (2015). Pengaruh Karakteristik Perusahaan, Kinerja Lingkungan, dan Liputan Media terhadap Environmental Disclosure. Accounting Analysis Journal, 4(3), 1-8.

[7] Babalola, Y. A. (2013). The Effect of Firm Size on Firms Profitability in Nigeria. Journal of Economics and Sustainable Development, 4(5), 90-94.

[8] Belkhir, M. (2009). Board of directors' size and Board of directors' size and performance in the banking industry. International Journal of Managerial Finance, 5(2), 201-221. 
[9] Certo, S. tREVIS. (2003). Influencing initial public offering investors with prestige: Signaling with board structures. Academy of Management Review, 28(3), 432-446.

[10] Ching, H. Y., \& Gerab, F. (2017). Sustainability Reports In Brazil Through The Lens Of Signaling, Legitimacy And Stakeholder Theories. Social Responsibility Journal, 13(1), 95-110. https://doi.org/10.1108/SRJ-10-2015-0147

[11] Choi, B. B., Lee, D., \& Psaros, J. (2013). An analysis of Australian company carbon emission disclosures. Pacific Accounting Review, 25 No.1(1), 58-79.

[12] Clarkson, P. M., Li, Y., Richardson, G. D., \& Vasvari, F. P. (2008). Revisiting the relation between environmental performance and environmental disclosure: An empirical analysis. Accounting, Organizations and Society, 33(4-5), 303-327. https://doi.org/ 10.1016/j.aos.2007.05.003

[13] Connelly, B. L., Certo, S. T., Ireland, R. D., \& Reutzel, C. R. (2011). Signaling Theory: A Review and Assessment. Journal of Management, 37(1), 39-67.

[14] Crisóstomo, V. L., Ftrire, F. S., \& Vasconellos, F. C. de. (2011). Corporate social responsibility, firm value and financial performance in Brazil. Social Responcibility Journal Research Gate, 7(2), 295-309.

[15] Doğan, M. (2013). Does Firm Size Affect The Firm Profitability? Evidence from Turkey. Research Journal of Finance and Accounting, 4(4), 53-60.

[16] Donnelly, R., \& Mulcahy, M. (2008). Board Structure , Ownership , and Voluntary Disclosure in Ireland. Journal Compilation, 16(5), 416-429.

[17] Gery Djajadikerta, H., \& Trireksani, T. (2012). Corporate Social and Environmental Disclosure by Indonesian Listed Companies on Their Corporate Web Sites. Journal of Applied Accounting Research, 13(1), 21-36.

[18] Ghomi, Z. B., \& Leung, P. (2013). An Empirical Analysis of the Determinants of Greenhouse Gas Voluntary Disclosure in Australia. Accounting and Finance Research, 2(1), 110-127. https://doi.org/10.5430/afr.v2n1p110

[19] Ghozali, I., \& Chariri, A. (2014). Teori Akuntansi International Financial Reporting System (IFRS) (pp. 439-444). Semarang: Badan Penerbit Universitas Diponegoro.

[20] Hidayat, A. A., \& Utama, S. (2003). Board Characteristics and Firm Performance: Evidence from Indonesia. International Research Journal of Business Studies, 8(3), 137-154.

[21] Hrasky, S. (2012). Carbon footprints and legitimation strategies: symbolism or action? Accounting, Auditing \& Acountability Journal, 25(1), 174-198.

[22] Irwhantoko, \& Basuki. (2016). Carbon Emission Disclosure: Studi pada Perusahaan Manufaktur Indonesia. Jurnal Akuntansi Dan Keuangan, 18(2), 92-104. 
[23] Jahamani, Y. F. (2003). Green Accounting in Developing Countries: The Case of U . A . E . and Jordan. Managerial Finance, 29(8), 37-45.

[24] Kalu, J. U., Buang, A., \& Aliagha, U. G. (2016). Determinants of voluntary carbon disclosure in the corporate real estate sector of Malaysia. Journal of Environmental Management, 182, 519-524.

[25] Kiliç, M., Kuzey, C., \& Uyar, A. (2015). The impact of ownership and board structure on Corporate Social Responsibility (CSR) reporting in the Turkish banking industry. Corporate Governance, 15(3), 357-374.

[26] Krishnamurti, C., \& Velayutham, E. (2017). The Influence Of Board Committee Structures On Voluntary Disclosure of Greenhouse Gas Emissions: Australian Evidence. Pacific-Basin Finance Journal, (September 2016). https://doi.org/10.1016/ j.pacfin.2017.09.003

[27] Lanis, R., \& Richardson, G. (2012). Corporate social responsibility and tax aggressiveness: a test of legitimacy theory. Accounting, Auditing \& Accountability Journal, 26(1), 75-100.

[28] Lester, D. L., \& Parnell, J. A. (2008). Firm size and environmental scanning pursuits across organizational life cycle stages. Journal of Small Business and Enterprise Development, 15(3), 540-554.

[29] Liao, L., Luo, L., \& Tang, Q. (2014). Gender diversity , board independence, environmental committee and greenhouse gas disclosure. The British Accounting Review, 47(4), 409-424.

[30] Liu, Y. S., \& Yang, J. H. (2018). A longitudinal analysis of corporate greenhouse gas disclosure strategy. The International Journal of Business in Society.

[31] Lodhia, S., \& Martin, N. (2012). Stakeholder responses to the National Greenhouse and Energy Reporting Act An agenda setting perspective. Accounting, Auditing \& Accountability Journal, 25(1), 126-145.

[32] Luo, L., \& Tang, Q. (2014). Does voluntary carbon disclosure reflect underlying carbon performance? Journal of Contemporary Accounting \& Economics, 10(3), 191205.

[33] Luo, L., Tang, Q., \& Lan, Y.-C. (2013). Comparison of propensity for carbon disclosure between developing and developed countries A resource constraint perspective. Accounting Research Journal, 26(1), 6-34.

[34] Martin, P. R., \& Moser, D. V. (2015). Managers ' green investment disclosures and investors '. Journal of Accounting and Economics, 1-16. https://doi.org/10.1016/j. jacceco.2015.08.004 
[35] Minnemeyer, S., Harris, N., \& Payne, O. (2018). Pelestarian Hutan Dapat Mengurangi Emisi Karbon Setara dengan Emisi Semua Mobil di Bumi.

[36] Mobus, J. L. (2005). Mandatory environmental disclosures in a legitimacy theory context. Accounting, Auditing \& Accountability Journal, 18(4), 492-517.

[37] Mujiyono, \& Nany, M. (2010). Pengaruh Leverage, Saham Publik, Size dan Komite Audit Terhadap Luas Pengungkapan Sukarela. Jurnal Dinamika Akuntansi, 2(2), 129134 .

[38] Niresh, J. A., \& Velnampy, T. (2014). Firm Size and Profitability: A Study of Listed Manufacturing Firms in Sri Lanka. International Journal of Business and Management, 9(4), 57-64.

[39] Nurkhin, A. (2010). Corporate governance dan Profitabilitas, Pengaruhnya terhadap Pengungkapan CSR Sosial Perusahaan. Jurnal Dinamika Akuntansi, 2(1), 46-55.

[40] Obradovich, J., \& Gill, A. (2012). The Impact of Corporate Governance and Financial Leverage on the Value of American Firms. International Research Journal of Finance and Economics, 9, 1-14.

[41] Peng, J., Sun, J., \& Luo, R. (2015). Corporate Voluntary Carbon Information Disclosure: Evidence from China's Listed Companies. World Economy, 38(1), 91-109. https://doi. org/10.1111/twec.12187

[42] Pratama, I. G. B. A., \& Wiksuana, I. G. B. (2016). Pengaruh Ukuran Perusahaan dan Leverage terhadap Nilai Perusahaan dengan Profitabilitas sebagai variabel Mediasi. E-Jurnal Manajemen Unud, 5(2), 1338-1367.

[43] Pratiwi, D. N. (2017). Pengaruh Stakeholder Terhadap Carbon Emission Disclosure, 2(01), 288-300.

[44] Primc, K., \& Čater, T. (2015). Environmental proactivity and firm performance: a fuzzy-set analysis. Management Decision, 53(3), 648-667.

[45] Putri, M. R., \& Zuraya, N. (2018). DKI Jakarta Targetkan Emisi Gas Rumah Kaca Turun 30 Persen.

[46] Qian, W., Hörisch, J., \& Schaltegger, S. (2017). Environmental management accounting and its effects on carbon management and disclosure quality. Journal of Cleaner Production, 174, 1608-1619.

[47] Rahman, N. R. A., Rasid, S. Z. A., \& Basiruddin, R. (2017). Board Effectiveness and Quality of Voluntary Carbon Reporting of Malaysian Companies. International Journal of Innovation and Business Strategy, 7(1), 1-9.

[48] Rankin, M., Windsor, C., \& Wahyuni, D. (2011). An investigation of voluntary corporate greenhouse gas emissions reporting in a market governance system. 
Accounting, Auditing \& Accountability Journal, 24(8), 1037-1070. https://doi.org/ $10.1108 / 09513571111184751$

[49] Safitri, N. M. Y., Wahyuni, M. A., \& Yuniarta, G. A. (2017). Pengaruh Kinerja Keuangan, Ukuran Perusahaan dan Struktur Kepemilikan Terhadap Profitabilitas. EJournal Universitas Pendidikan Ganesha, 7(1).

[50] Saka, C., \& Oshika, T. (2014). Disclosure effects, carbon emissions and corporate value. Sustainability Accounting, Management and Policy Journal, 5(Research рарег), 22-45.

[51] Tarighi Angle, I., Rezanezhad, M., \& Tarighi, H. (2017). The relationship between board of directors' structure and company ownership with corporate social responsibility disclosure. Humanomics, 33(4), 398-418. https://doi.org/10.1108/H02-2017-0022

[52] Torchia, M., \& Calabrò, A. (2016). Board of directors and financial transparency and disclosure. Evidence from Italy. The International Journal of Business in Society, $16(2), 420-436$.

[53] Tunggal, W. S. P., \& Facrurrozie. (2014). Pengaruh Environmental Performance, Environmental Cost dan CSR Disclosure Terhadap Financial Performance. Accounting Analysis Journal, 3(3), 310-320.

[54] Villiers, C. de, Naiker, V., \& Staden, C. J. Van. (2011). The Effect of Board Characteristics on Firm Environmental Performance. Journal of Management, 37(6), $1636-1663$.

[55] Widiastuti, N. A., Arifati, R., \& Abrar. (2016). Journal Of Accounting, Volume 2 No.2 Maret 2016. Journal of Accounting, 2(2).

[56] Widyati, M. F. (2013). Pengaruh Dewan Direksi, Komisaris Indepeden, Komite Audit, Kepemilikan Manajerial dan Kepemilikan Institusional terhadap Kinerja Keuangan. Jurnal Ilmu Manajemen, 1(1), 234-249.

[57] Winarsih, A. M., \& Solikhah, B. (2015). Pengaruh Media, Sensitivitas Industri dan Struktur Corporate Governance Terhadap Kualitas Environmental Disclosure (Studi Pada Perusahaan High Profile di Bursa Efek Indonesia Periode 2011-2013). Accounting Analysis Journal, 4(2), 1-9.

[58] Yanto, H., \& Muzzammil, B. S. (2016). A Long Way to Implement Environmental Reporting In Indonesian Mining Companies. International Journal of Applied Business and Economic Research, 14(40), 6493-6514. 
[59] Yuliana, R. (2008). Pengaruh Karakteristik Perusahaan Terhadap Pengungkapan Corporat Social Responsibility (CSR) dan Dampaknya Terhadap Reaksi Investor. Jumal Akuntansi Dan Keuangan Indonesia, 5, 245-276. 